\title{
Potential relationships between atmospheric particulate matter transported by winter monsoons and red tides in the East China Sea
}

\author{
WENG HuanXin*, TIAN RongXiang, JI ZhongQiang \& YU XinAn \\ Institute of Environment and Biogeochemistry, Zhejiang University, Hangzhou 310027, China
}

Received January 5, 2010; accepted June 18, 2010

\begin{abstract}
Combining numerical diagnosis from atmospheric science with biogeochemical methods, a model of the potential correlation of monsoons with red tide emergence in the East China Sea is constructed. The model is designed based on an in-depth investigation of the time-space relationship of aerosol and red tide events in the East China Sea from 2005 to 2006, and a continuous monitoring of atmospheric particulates at two stations. The study shows that every red tide event investigated has a close relationship with aerosols coming from the northwest (wind direction in winter) along with subsidence flow. The elemental abundance of total suspended particulate in Hangzhou and Tiantai is different from that of soil background levels, indicating atmospheric particulates there are brought in by winter winds. There is a significant correlation between the content of iron and phosphorous in atmospheric particulates, which mainly exist in binding materials between particulates. In addition, the confined absorption of iron and phosphorous by red tides is related to the intensity of sunlight. These results provide new information regarding the mechanism for the high frequency of red tides in the East China Sea. The results also provide a scientific basis for establishing new pathways for pre-warning and forecasting of red tide disasters.
\end{abstract}

winter monsoon, atmospheric particulate matter, red tide in East China Sea, iron nutrient element limitation

Citation: Weng H X, Tian R X, Ji Z Q, et al. Potential relationships between atmospheric particulate matter transported by winter monsoons and red tides in the East China Sea. Chinese Sci Bull, 2011, 56: 297-305, doi: 10.1007/s11434-010-4209-x

Historically, rivers have been considered to be the main source of various geochemical components in the ocean. However, in the 1970s, it was realized that the atmosphere also contributes many important components to the deep ocean, including sediments, and atmospheric deposition affects primary production in estuaries, coasts and oceans [1-3]. In addition, the rate of atmospheric particulate matter (APM) deposition is highly variable [4-8]. In fact, atmospheric transportation supports $95 \%$ of the iron needed by phytoplankton in the ocean [9].

In recent years, red tide disasters have increased globally because of an increase in the worldwide pollution of coastal environments [10]. Frequent occurrences of red tides have resulted in serious ecological and environment problems within coastal areas. For example, fish, shrimp and seashell

*Corresponding author (email: gswenghx@zju.edu.cn) die-offs have caused severe economic losses in some regions. Red tides are considered an abnormal ecological phenomenon, and are indicated by an unusual water color as a result of the proliferation of microalgae, protozoans and bacteria during unique oceanographic conditions [11]. Thus, red tides are the result of a combination of physical, chemical, biological and meteorological factors [12]. Therefore, it is difficult to identify the specific mechanism responsible for red tide occurrences. However, observations and experimentation have identified the importance of meteorological and ocean nutritional conditions as two key factors that induce red tides. Long-term meteorological studies have highlighted seasonal variations [13], high precipitation and rising temperatures as conditions likely to lead to red tides. In addition, moderate wind speeds, high temperatures, sufficient sunlight and El Niño phenomena have been recorded during red tides [14]. With regard to nutrient conditions, in 
situ surveys and simulation tests also have identified trace elements (i.e. iron) and major nutrients (e.g. nitrogen, phosphorous, silicon) as prerequisites for the growth of red tide biomass [15]. Previous research on the identification of red tide pathways has focused mainly on the effect of excess nutrients transported by river and surface runoff to the ocean, while ignoring the effect of atmospheric transportation. However, recent studies have begun to identify the important contribution of nutrients transported by air to the ocean, and their triggering of different types of red tides [16,17].

Since we know little about the causal relationship between air-transported nutrients and red tide occurrences, it is difficult to identify the mechanism that generates red tides, and it is challenging to accurately forewarn and forecast red tide events to effectively prevent disasters. After systematically analyzing aerosol indices and meteorological field data, this research combined the analytical result of iron and phosphorous contents at field stations with iron speciation in APM above the Zhejiang coastal area. The results of simulation tests on iron and phosphorous uptake by red tide algae under different sunlight intensities are used to propose a potential correlation model between the trace elements transported by monsoons and the occurrence of red tides in the East China Sea. This model is based on the correspondence between aerosol and red tide events that took place in the East China Sea in 2005 and 2006. This study therefore presents a new interpretation for the frequent occurrence of red tides in the East China Sea and along the coast of China. This work also provides essential parameters for forecasting red tide disasters.

\section{Methods}

Red tide records from 2005 to 2006 were obtained from the Marine Bulletin, announced by the State Oceanic Administration and the Marine Environmental Quality Bulletin of the China Oceanic Information Network. Meteorological data for the same years were calculated from the daily mean reanalyzed data of the National Centers for Environmental Prediction (NCEP), with horizontal ( $\mathrm{u}, \mathrm{v}$ components) and vertical (omega component) velocities from 10 altitudes (1000, 925, 850, 700, 600, 500, 400, 300, 250 and $200 \mathrm{hPa})$. The aerosol data were obtained from the NASA Goddard Space Flight Center. Aerosol Index is the daily observation datum of ozone and reflectivity measured by an ozone monitoring instrument (OMI).

The red tide events that took place in the East China Sea study area $\left(100^{\circ}-150^{\circ} \mathrm{E}, 0^{\circ}-50^{\circ} \mathrm{N}\right)$ between 2005 and 2006 were used to establish a relationship between monsoontransported atmospheric particles and frequency of red tide occurrence. The results were systematically analyzed and are discussed according to the atmospheric horizontal flow field and vertical velocity field during 2005, and between
April and August of 2006, and the variation of OMI aerosol index before and after red tides. These data were combined with total suspended particulate (TSP) continuous data for a period of 1 year in two stations, and using Grid Analysis and Display System (GRADS) software.

The two APM observation stations are located at the coastal cities of Tiantai and Hangzhou in Zhejiang. The sampling points chosen were far away from urban air pollution areas, and the sampling time was from January to December 2005 for the Hangzhou station, and from April 2005 to April 2006 for the Tiantai station. Sampling was conducted through $24 \mathrm{~h}$ from 8 a.m. to 8 a.m. the next day. The TSP sampling procedure was conducted in accordance with the national standard GB/T6921-86. This procedure included pumping samples through a high-flow TSP sampler and using glass fiber filter membranes with a pore size of $0.45 \mu \mathrm{m}$. The filter membranes were kept in a desiccator at a constant temperature for 48 hours before and after sampling. The weight of the membranes was obtained before and after sampling with an electronic balance. Then, the membranes were sealed in a PTFE plastic bag for cryopreservation. The flow rate was maintained at $1.0 \mathrm{~m}^{3} / \mathrm{min}$, and a record was kept of temperature, humidity, wind speed and weather conditions for each sampling location. To avoid anthropogenic contamination, plastic gloves were worn during the above sampling process.

Elemental analysis of the APM was conducted as follows. A $4 \mathrm{~cm} \times 4 \mathrm{~cm}$ piece of membrane was removed from each sample and placed in a 25-mL PTFE beaker. A 6-mL $\mathrm{HNO}_{3}-\mathrm{HClO}_{4}$ solution (volume ratio of $4: 2$ ) was added to the beaker and covered with a glass dish. The solution was heated at $170{ }^{\circ} \mathrm{C}$ for about 5 hours on a heating plate until the filter membrane turned white. Then, the glass dish was removed to evaporate the perchlorate. Once the membranes were dried, the beaker was removed from the heating plate and cooled down to room temperature. Then, the membranes were washed three times using secondary deionized water. This solution was subsequently transferred into a 50-mL volumetric flask, and filled with deionized water to a standard volume. The iron and phosphorous concentrations were determined using inductively coupled plasma atomic emission spectroscopy. All sample measurements were calibrated with blank membrane. In order to identify the bioavailability of iron in the TSP, an optimized BCR method was employed to analyze iron speciation [18]. To obtain the soluble fraction, a $6 \mathrm{~cm} \times 6 \mathrm{~cm}$ piece of membrane from each sample was introduced into a $50-\mathrm{mL}$ centrifuge tube. Then, $15-\mathrm{mL}$ of deionized water was added to each tube. Oscillation of the samples followed for $15 \mathrm{~h}$ at room temperature. After this time, the samples were filtered through a $0.45 \mu \mathrm{m}$ microporous membrane under vacuum. Subsequently the tubes and samples were washed three times with $2 \mathrm{~mL}$ deionized water. The filtrates and filter membranes also were washed three times with $1 \mathrm{~mL}$ of deionized water. The resulting solutions were collected and 
scaled to $25 \mathrm{~mL}$. The reducible fraction was analyzed by placing the residual filtered samples from the previous procedure in a centrifuge tube with $10 \mathrm{~mL}$ of $0.25 \mathrm{~mol} / \mathrm{L}$ hydroxylamine hydrochloride. Then, the $\mathrm{pH}$ was adjusted to 2 by adding $\mathrm{HNO}_{3}$. The samples were then oscillated at room temperature for $15 \mathrm{~h}$. Again, the samples were filtered through a $0.45 \mu \mathrm{m}$ microporous membrane under vacuum, the tubes and samples were washed three times with $2 \mathrm{~mL}$ deionized water and the filtrates and filter membranes were washed three times with $1 \mathrm{~mL}$ deionized water. The collected solutions were then scaled to a volume of $25 \mathrm{~mL}$. The oxidizable fraction was analyzed by placing the residual filtered samples from the previous section in a centrifuge tube, and adding $10 \mathrm{~mL}$ of $30 \% \mathrm{H}_{2} \mathrm{O}_{2}$. These samples were then placed in a water bath of $95 \pm 1^{\circ} \mathrm{C}$ for organic matter digestion. When the solutions were almost dried, $10 \mathrm{~mL}$ of $30 \% \mathrm{H}_{2} \mathrm{O}_{2}$ was added to continue the digestion until the solution was dried. During this procedure, the tubes were oscillated. After digestion, the samples were cooled in the centrifuge tubes, and $20 \mathrm{~mL}$ of $2.5 \mathrm{~mol} / \mathrm{L} \mathrm{NH} \mathrm{NHAC}_{4} \mathrm{Oas}$ added, followed by adjusting the $\mathrm{pH}$ to 3 with concentrated nitric acid and oscillating at room temperature for $15 \mathrm{~h}$. After filtering through a $0.45 \mu \mathrm{m}$ microporous membrane under vacuum, the tubes and samples were washed three times with $2 \mathrm{~mL}$ of deionized water and the filtrates and filter membranes were washed three times with $1 \mathrm{~mL}$ of deionized water. The final solutions were collected and made up to $50 \mathrm{~mL}$ with deionized water. At the same time, a blank control was used to obtain the relative standard deviations for the inductively coupled plasma atomic emission spectroscopy to a repeatable analysis of less than 5\% deviation. APM samples were analyzed by transmission electron microscopy. To understand the influence of light intensity on iron and phosphorus uptake of red tide algae under simulated conditions, Cryptophyta, a common alga along the coast of China, was chosen as a model alga to analyze the uptake of iron and phosphorus under different light intensities per unit of algal cells $\left(10^{6}\right)$.

\section{Results and discussion}

\subsection{Spatial and temporal relationships between red tides in the East China Sea and aerosol events}

Table 1 lists the red tide events that took place in the East China Sea during 2005 and 2006 within an area larger than $300 \mathrm{~km}^{2}$ and the records of aerosol events. From Table 1, it is evident that red tide events larger than $1000 \mathrm{~km}^{2}$ occurred 7 and 6 times in 2005 and 2006, respectively. The main algal species of red tides were Skeletonema costatum, Prorocentrum dentatum Stein and Karenia mikimotoi Hansen in both years. Except for the red tide of April 2005, there was a record of an aerosol event on the day of or before every red tide event, indicating a close relationship with aerosol events, especially the large-scale red tide events. Figure 1 shows the distribution of aerosols above the East China Sea on May 24 and 30, June 2, 3 and 15, 2005. According to Figure 1, aerosols appeared above the Yangtze River Estuary on May 24, and were followed by a red tide area of about $7000 \mathrm{~km}^{2}$ in the sea just outside of Yangtze River estuary. The algal biomass of this tide was composed of $S$. costatum and Thalassiosira, and it lasted until June 1. On May 30, there was an aerosol event above Hangzhou Bay. This event was followed by a red tide near Nanji Island, Pingyang, Zhejiang. This red tide lasted until June 9, and had a maximum area of about $500 \mathrm{~km}^{2}$. The dominant algal species were $K$. mikimotoi Hansen and $P$. dentatum Stein. On June 2 and 3, an aerosol event appeared above the East China Sea, and was followed by a red tide in the sea near the Taohua, Xiazhi and Jiushan islands during June 3-5. This red tide had a maximum area of $2000 \mathrm{~km}^{2}$, and was dominated by $K$. mikimotoi Hansen and P. dentatum Stein. On June 6, aerosols appeared above and south of Yangtze River Estuary, and on June 8, about $2120 \mathrm{~km}^{2}$ of sea area out of Yangtze River Estuary was covered with red tides caused by $S$. costatum. Then, between June 8 and 11, $P$. dentatum Stein and $K$. mikimotoi Hansen produced a red tide over a sea area of $1300 \mathrm{~km}^{2}$ from Shengshan to West Lühuashan in Zhejiang. From June 8 to 15, an area of 1600 $\mathrm{km}^{2}$ from Songlanshan to Tantoushan, Zhejiang, was covered with a red tide produced by Gymnodinium mikimotoi Miyake. In addition, aerosols were observed above the Yangtze River Estuary and southern regions on June 15. The next day, red tides dominated by Thalassiosira rotula, $S$. costatum and $P$. dentatum Stein covered $300 \mathrm{~km}^{2}$ near Zhoushan, Zhejiang. After June 15, no aerosol events were observed in the northwestern region of the East China Sea, except for a small event above Hangzhou Bay on June 24. According to the Bulletin of Monsoon Monitoring in East Asia, reported by the National Climatic Data Center of China Meteorological Administration [19], the summer monsoon onset from the South China Sea began around May 25-30, 2005. Thus, the aerosols above Hangzhou Bay on June 24 were brought near the coast by the offshore East Asian summer monsoon. Since no red tides were observed during this time, it is assumed that aerosols coming ashore from the sea lacked the necessary nutrients to form coastal red tides. Conversely, no red tides were formed on July 1, 2 or 7, although aerosols were observed. After that, no aerosols appeared and no red tides occurred.

Figure 2 shows the distribution of aerosols above the East China Sea in May and June of 2006. The pattern presented in Figure 2 is similar to that of 2005. The area above Linhai, Zhejiang, and the northern sea area were covered with aerosols on May 2-4. Then, on May 3-8, a red tide of $P$. dentatum Stein and $S$. costatum formed in an area of 100 $\mathrm{km}^{2}$, just offshore of Zhoushan and Southeast, Liuheng Island. This was the first large-area red tide event in the East China Sea in 2006. No aerosol event appeared above the East China Sea on May 5-8. After that, aerosols from the 
Table 1 Red tide events in the East China Sea and the record of aerosol events in 2005 and 2006

\begin{tabular}{|c|c|c|c|c|c|}
\hline \multicolumn{3}{|c|}{ Time } & \multirow{2}{*}{ Location } & \multirow{2}{*}{ Area $\left(\mathrm{km}^{2}\right)$} & \multirow{2}{*}{ Red tide biomass } \\
\hline & Red tide events & Aerosol records & & & \\
\hline \multirow{10}{*}{2005} & April 1 & & Middle and south of Zhejiang & 3000 & Skeletonema costatum, Thalassiosira \\
\hline & May 24 - June 1 & May 24 & Outer Yangtze River estuary & 7000 & Skeletonema costatum, Thalassiosira \\
\hline & May 30 - June 9 & May 30 & Nanji Island, Pingyang, Zhejiang & 500 & Mikimotoi Hansen, Prorocentrum dentatum \\
\hline & June $3-5$ & June $2-3$ & $\begin{array}{c}\text { Taohua, Xiazhi and Jiushan islands, } \\
\text { Zhejiang }\end{array}$ & 2000 & $\begin{array}{c}\text { Prorocentrum dentatum Stein, Karenia mikimotoi } \\
\text { Hansen }\end{array}$ \\
\hline & June 8 & June 6 & Outer Yangtze River estuary & 2120 & Skeletonema costatum \\
\hline & June $8-11$ & June 6 & Shengshan to West Lühuashan, Zhejiang & 1300 & $\begin{array}{c}\text { Prorocentrum dentatum Stein, Karenia mikimotoi } \\
\text { Hansen }\end{array}$ \\
\hline & June $8-15$ & June 6 & $\begin{array}{l}\text { Songlanshan to Tantoushan, Zhejiang } \\
\text { (out of the red tide monitoring areas) }\end{array}$ & 1600 & Gymnodinium mikimotoi Miyake \\
\hline & June $10-13$ & June 6 & South of Jiushan Island, Zhejiang & 2000 & $\begin{array}{c}\text { Prorocentrum dentatum Stein, Karenia mikimotoi } \\
\text { Hansen }\end{array}$ \\
\hline & June $15-21$ & June 15 & Yangtze River estuary & 400 & Skeletonema costatum \\
\hline & June 16 & June 15 & Zhoushan, Zhejiang & 300 & $\begin{array}{l}\text { Thalassiosira rotula, Skeletonema costatum, } \\
\text { Prorocentrum dentatum Stein } \\
\end{array}$ \\
\hline \multirow{6}{*}{2006} & May $3-8$ & May $2-4$ & $\begin{array}{l}\text { Zhoushan to southeast of Liuheng } \\
\text { Island, Zhejiang }\end{array}$ & 1000 & Prorocentrum dentatum Stein, Skeletonema costatum \\
\hline & May $14-17$ & May 11 & Outer Yangtze River estuary & 1000 & $\begin{array}{c}\text { Prorocentrum dentatum Stein, Karenia mikimotoi } \\
\text { Hansen }\end{array}$ \\
\hline & May $20-27$ & May $19-20,23,27$ & Yushan Island & 3000 & $\begin{array}{c}\text { Prorocentrum dentatum Stein, Karenia mikimotoi } \\
\text { Hansen }\end{array}$ \\
\hline & June $12-14$ & June $9-12$ & $\begin{array}{l}\text { South of Zhejiang (Dongtou Island to } \\
\text { Beiji Island) }\end{array}$ & 2100 & $\begin{array}{c}\text { Prorocentrum dentatum Stein, Karenia mikimotoi } \\
\text { Hansen }\end{array}$ \\
\hline & June $15-21$ & June 15 & Yushan Island and Xiangshan & 1000 & Prorocentrum dentatum Stein, Mesodinium rubrum \\
\hline & June $24-27$ & June 19 & $\begin{array}{c}\text { Yushan and Jiushan islands, middle of } \\
\text { Zhejiang }\end{array}$ & 1200 & Chaetoceros curvisetus, Karenia mikimotoi Hansen \\
\hline
\end{tabular}
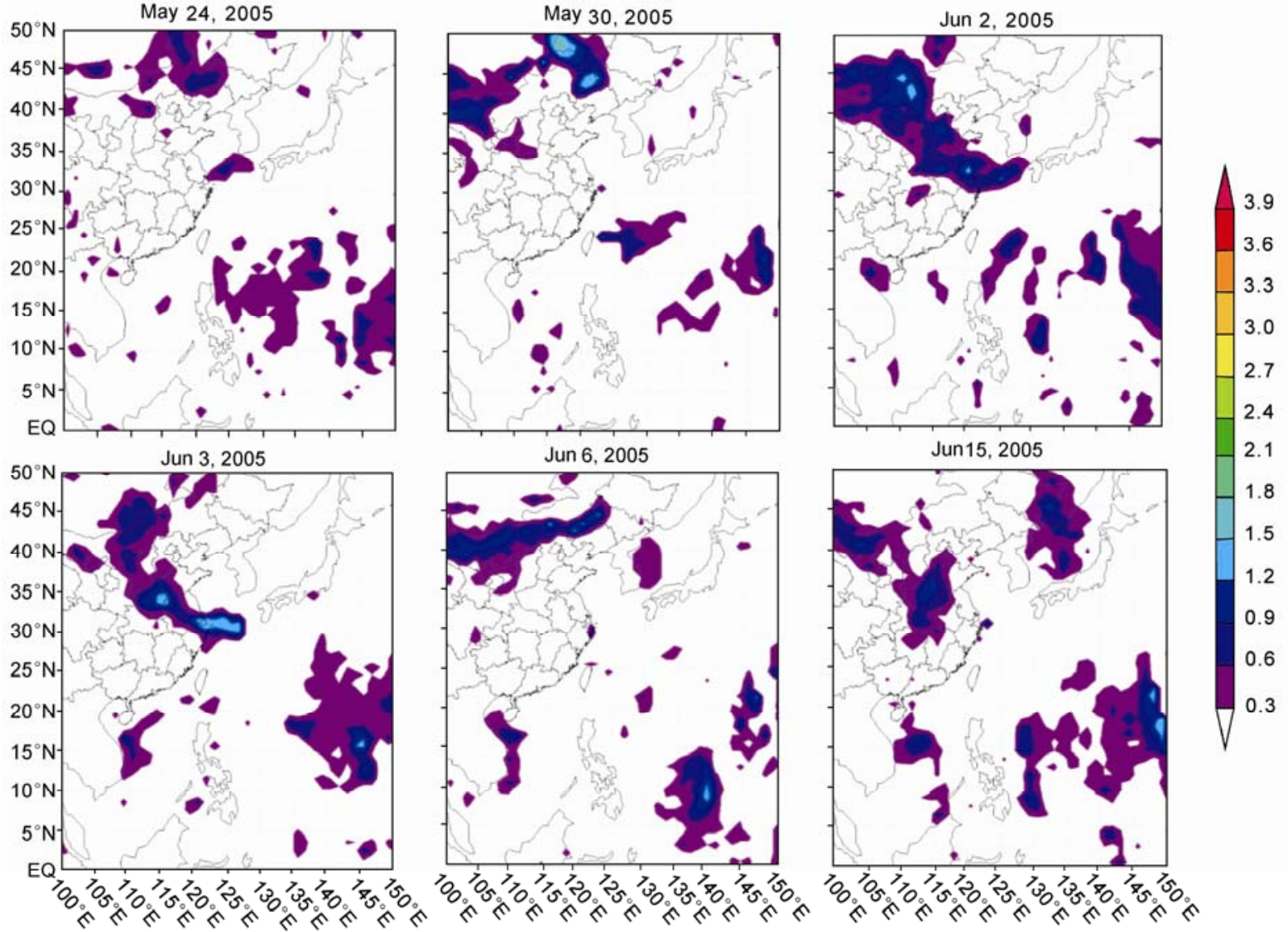

Figure 1 Distribution of OMI aerosol indices above the East China Sea from May 24 to June 18, 2005. 
Pacific Ocean were observed above Wenzhou, Zhejiang, on May 9, and no red tide occurred in the East China Sea. Aerosols above the Yangtze River Estuary on May 11 were followed by a red tide of $P$. dentatum Stein and $K$. mikimotoi Hansen covering a sea area of $100 \mathrm{~km}^{2}$ outside the Yangtze River Estuary. Another aerosol event above the East China Sea on May 19-20, with a supplement of two aerosol events on May 23 and 27, was observed, corresponding to a red tide of $P$. dentatum Stein and $K$. mikimotoi Hansen. This red tide occurred near the Yushan Islands, Zhejiang, and covered a sea area of $3000 \mathrm{~km}^{2}$. During June 9-12, aerosols arriving from the northwest were recorded above the the coastal area along Zhejiang and in the Yangtze River Estuary. Then, on June 12-14, a red tide of $P$. dentatum Stein and $K$. mikimotoi Hansen formed in an area of $2100 \mathrm{~km}^{2}$ near Dongtou and Beiji islands, south of Zhejiang. The aerosols near Yangtze River Estuary on June 15 corresponded with a red tide of $P$. dentatum Stein and Mesodinium rubrum over a sea area of $1000 \mathrm{~km}^{2}$ near Yushan Island and Xiangshan, Zhejiang. Aerosols were recorded on June 19 above the Yangtze River Estuary and Hangzhou Bay. A red tide of Chaetoceros curvisetus and $K$. mikimotoi Hansen was recorded a few days later, extending over a sea area of $1200 \mathrm{~km}^{2}$ near Yushan and Jiushan islands. Following this event, no aerosols were recorded from the northwest and no red tides were observed over the East China Sea. According to the Bulletin of Monsoon Monitoring in East Asia, reported by the National Climatic Data Center of China Meteorological Administration [20], the summer monsoon onset from the South China Sea began around May 15-20, 2006. From this time to just after July, the wind direction was maintained

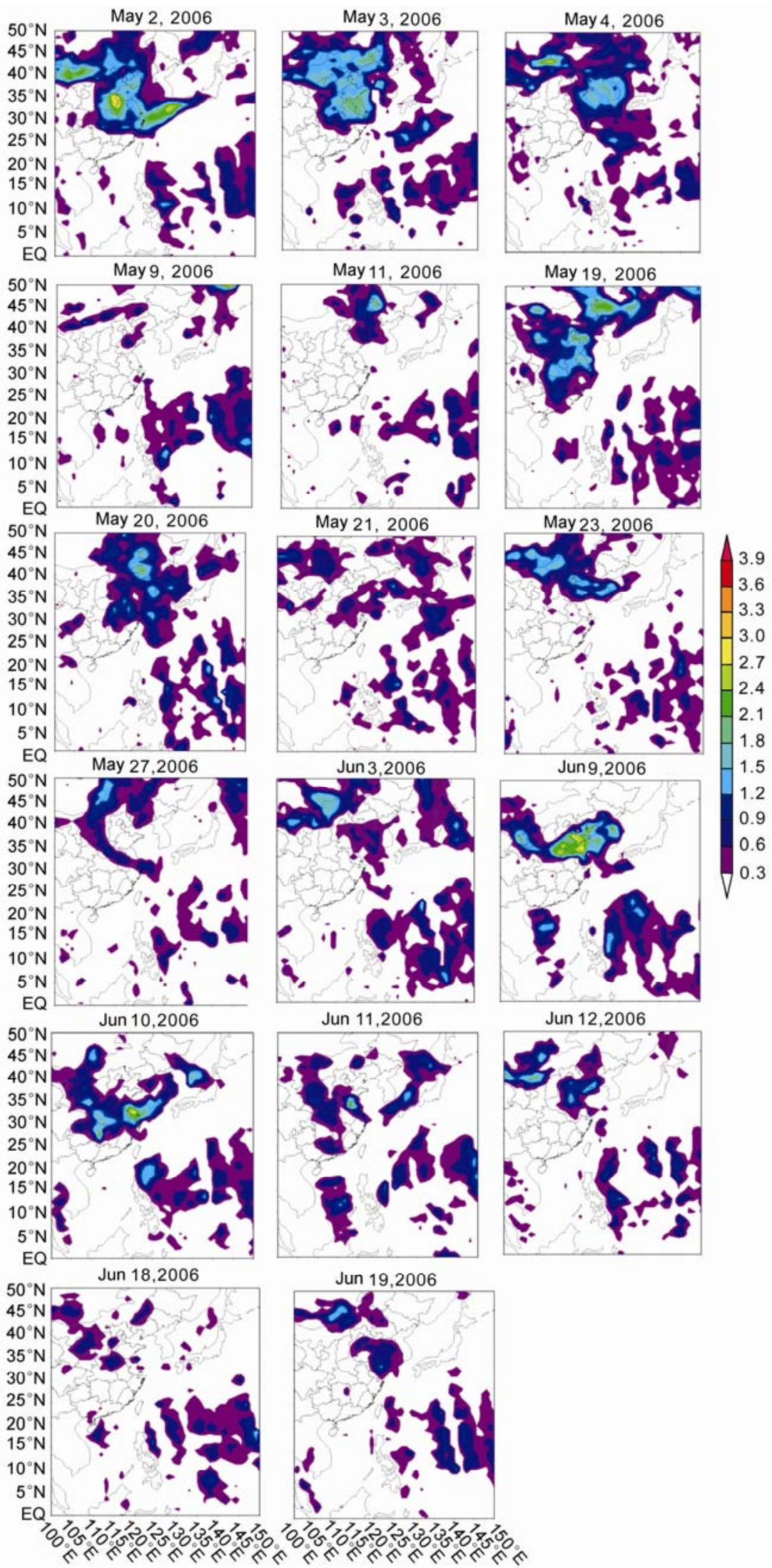

Figure 2 Distribution of OMI aerosol index above the East China Sea on May and July of 2006. 
southerly, and produced aerosols on July 13 and 29, but no red tides followed.

Through the analysis of spatial and temporal relationships between red tides in the East China Sea and aerosol events in 2005 and May to July, 2006, it is evident that every red tide event during this 2-year period was accompanied by an aerosol event from the northwest. In addition, the outbreak of red tides tends to occur over the same time or a few days after the aerosol event arrival. This pattern illustrates a consistency of red tide events and aerosol records in time and space. It is common that for a few days after an aerosol event appears, red tide events occur, which implies that the appearance of aerosols from the northwest may be a critical inducing factor to the large-scale outbreak of red tide events in this region.

For an in-depth understanding of the causal relationship between aerosol deposition and the occurrence of red tides, a vertical velocity analysis was conducted on the flow field: $\omega=\mathrm{d} P / \mathrm{d} t(\mathrm{~Pa} / \mathrm{s})$, where a positive $\omega$ represents a downdraft or updraft. Figure 3 shows the vertical velocity $(\omega)$ profile of air flow above the East China Sea during the red tide event of May 24, 2005. According to Figure 3, a downdraft was observed between latitudes $30^{\circ}$ and $34^{\circ} \mathrm{N}$ on May 24, 2005 , and aerosols also were recorded in this latitude interval (Figure 1). This trend suggests that aerosols were continuously delivered to the sea area through downdrafts. This event corresponded to a red tide just offshore of Yangtze River Estuary. After analyzing the vertical velocity of aerosols in 2005 and 2006, it was found that aerosol downdrafts above the East China Sea took place before every red tide. This indicates that aerosols were delivered to the sea where the red tide appeared. Thus, this pattern points to a causal relationship between aerosols and red tides.

\subsection{Iron and phosphorus in APM}

The suggestion of a causal relationship between aerosols

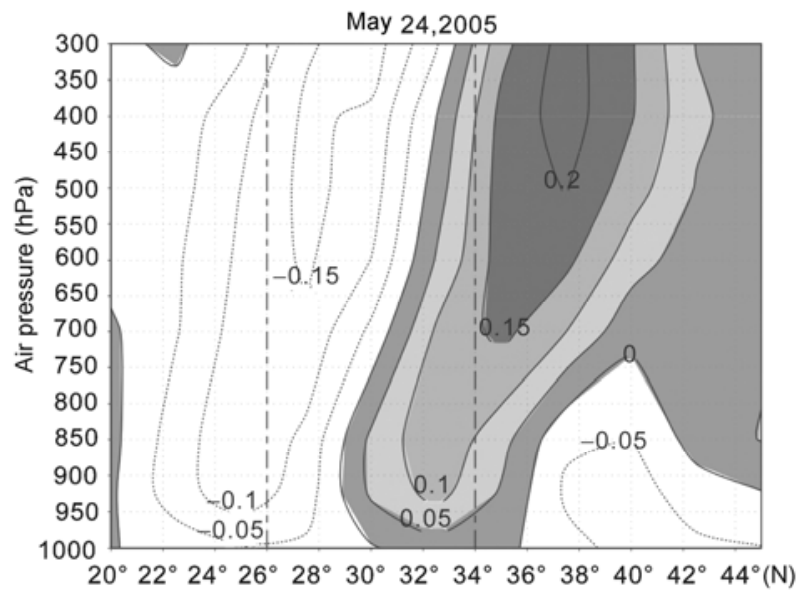

Figure 3 Vertical velocity $(\mathrm{Pa} / \mathrm{s})$ profile of the air flow above the East China Sea on May 24, 2005. and red tides is based on a process by which aerosols may supply red tide algae the limiting nutrients, such as iron and phosphorus, necessary to bloom. Previous researchers have stated that, in some ocean areas, despite a high concentration of nutrients (nitrogen and phosphorus), chlorophyll content is low because of iron limitation [1,21,22]. The main sources of iron in euphotic layers are: (1) river inputs, (2) wet and dry atmospheric deposition, and (3) re-suspension and dissolution of bottom sediment [23]. However, only a limited input of iron and phosphorus from rivers can be absorbed and utilized directly by halobios [24]. The remaining amount of these elements is deposited by mechanical, chemical and biological means, and accumulates in the bottom sediments of estuaries and bays in a metastable state. Then, the dissolution of iron from sediments relies on hydrodynamic conditions. Therefore, the delivery of bioavailable iron by APM is a key factor in inducing red tides.

Figure 4 illustrates the correlation of iron and phosphorus in the TSP collected at the Hangzhou and Tiantai stations. From Figure 4, it is apparent that, although TSP in Hangzhou and Tiantai differed in their total iron and total phosphorus contents, a significant correlation was found, with correlation coefficients $(R)$ of 0.7731 and $0.4375, P<0.01$, respectively. This correlation indicates that both iron and phosphorus nutrients are needed by phytoplankton and that these elements were delivered through atmospheric particulate matter.
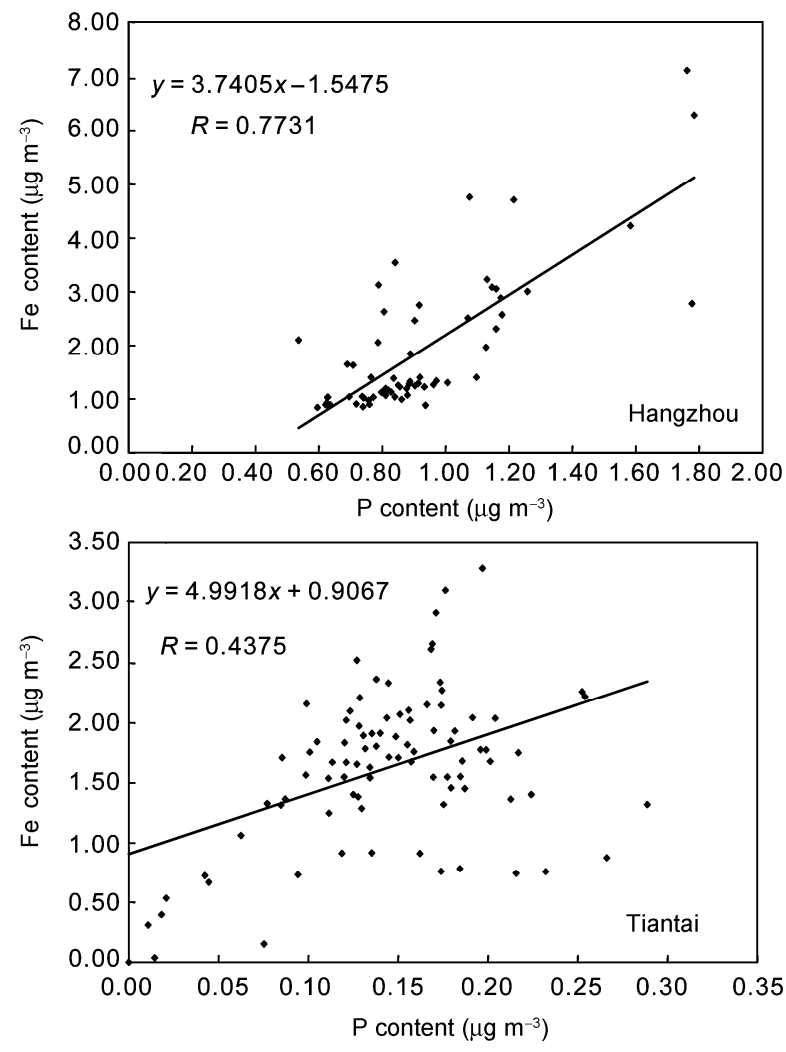

Figure 4 Correlation of total $\mathrm{P}$ and total $\mathrm{Fe}$ in TSP. 
Bioavailability of iron nutrients is related not only to the amount of these nutrients, but also depends on their binding forms. Soluble fractions of iron can migrate easily into the environment and can be used by phytoplankton. Reducible and oxidizable fractions of iron also can enter into the environment and be used by phytoplankton under suitable conditions. Thus, soluble, reducible and oxidizable fractions of iron all have the potential for bioavailability. The total iron content in the TSP at the Hangzhou and Tiantai stations was $1.238 \mu \mathrm{g} / \mathrm{m}^{3}$ (standard deviation of 0.5905 ) and 0.5442 $\mu \mathrm{g} / \mathrm{m}^{3}$ (standard deviation of 0.1227 ), respectively. Figure 5 illustrates iron content variations of the three different binding forms at the two stations for different months. At the Hangzhou station, iron contents of different binding forms in TSP were higher from February to April, and November to December, and were lower from July to September. A similar pattern was observed in Tiantai. This pattern was related to a change in particulate composition delivered by different monsoons, and indicates that the composition of APM varies in time and space. In addition, at both the Hangzhou and Tiantai stations, soluble fractions of iron were the main forms in the TSP. The reducible fraction followed, and the oxidizable fraction was the least dominant fraction.

Previous studies have shown a synergistic effect of iron and phosphorus uptake by red tide algae [25]. In addition to phosphorus and nitrogen, red tide algae also absorb a high quantity of iron. Iron is essential for phytoplankton growth processes, such as electronic delivery, oxygen metabolism, nitrogen uptake and utilization, and photosynthesis and respiration. Thus, phosphorus and iron in Cryptophyta are significantly correlated. Only $5 \%$ of terrestrial phosphorus can be directly absorbed by marine organisms [26], and even less for terrestrial iron [1]. This limitation makes atmospheric transport especially important when sea water is stratified in summer. After analyzing iron contents in the
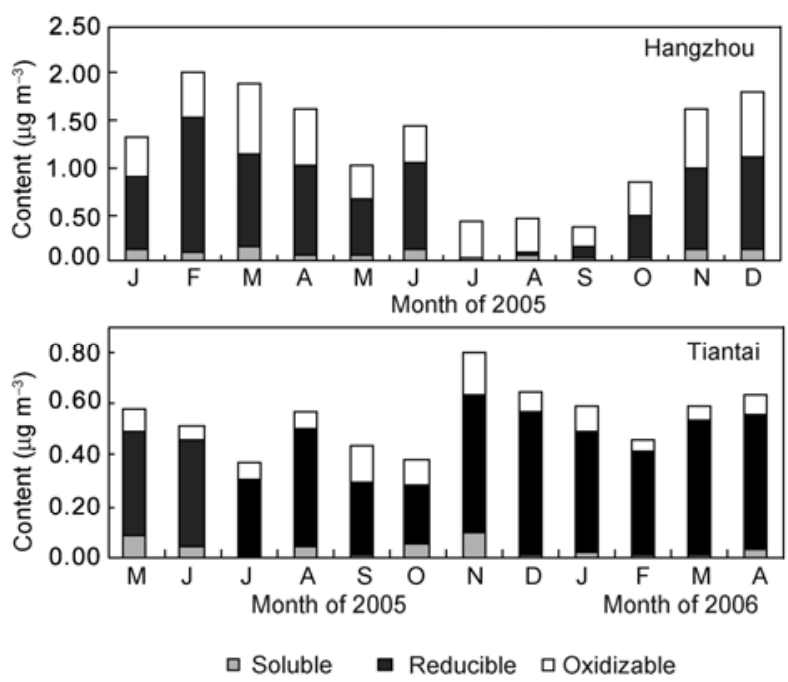

Figure 5 Seasonal differences in iron content with different binding forms in TSP.
APM of different particle sizes, it was found that particle sizes of $2 \mu \mathrm{m}$ contained $1.02 \%$ of iron, and particle sizes of $10 \mu \mathrm{m}$ up to $27.64 \% \mathrm{Fe}$. Figure 6 shows a transmission electron microscope image of a large-sized particle of APM, which is composed of many small particles. In this photo, the small-sized particle is surrounded by a layer of cement on the surface, which accumulates small particles together to form a larger particle (Figure 6(a),(b)). In addition, it also can be observed that $\mathrm{SiO}_{2}$ is the component in the core of the particle, and that the iron mainly exists as cement between the particulate grains. After extraction with artificial seawater, most particles separated, and most of the cements disappeared (i.e. large particles dispersed into smaller particles (Figure 6(c), (d)). This indicates that when atmospheric particles settle into the seawater, the cement between particles dissolve into the water. As a result, iron, phosphorus and other nutrients in the cements dissolve into the sea, making the needed nutrients available for red tide organisms, and favoring the subsequent outbreak of a red tide. This process may be the main factor in establishing the causal relationship between monsoons and red tides.
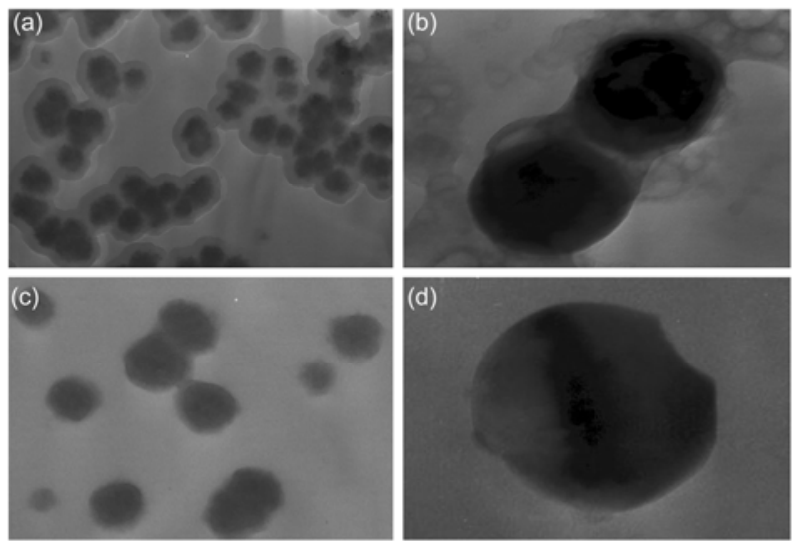

Figure 6 Photo of APM by transmission electron microscope. (a) and (b) before extraction $\times 50000$; (c) and (d) after extraction $\times 59000$.

\subsection{Relationship between monsoons and red tides}

Previous studies on red tides $[14,27,28]$ have found that the climatic conditions invariably are sunny when red tides occur, or just before they take place. Thus, fine weather is considered a beneficial meteorological condition for the outbreak of red tides. This fine weather is related to the vertical movement of air flow. Upward movement of air flow forms clouds and rain, while downward movement of air flow forms fine weather [29]. In other words, downdrafts not only provide the limiting nutrients like phosphorous and iron, as aerosol transports of APM to the ocean, but also favorable weather conditions for the outbreak of red tides.

Simulation tests were designed to explore the underpinning reasons of fine weather favoring red tides [30]. It was found that, under low light intensities, the amount of iron 
and phosphorus absorbed by algal cells was much higher than under high light intensities (Figure 7). This relationship can be observed in Figure 7, where the amount of iron and phosphorus absorbed by algal cells is shown to be 2.5 and 1.9 times higher under light intensity of $10 \mu \mathrm{mol} /\left(\mathrm{m}^{2} \mathrm{~s}\right)$ compared with that in $100 \mu \mathrm{mol} /\left(\mathrm{m}^{2} \mathrm{~s}\right)$, respectively. Thus, in clear weather, the limiting iron and phosphorus nutrients were in less demand for algal growth than during cloudy and rainy days. Thus, the simulation test corroborates the fact that red tides often occur in fine weather.

At the conversion season of winter and summer monsoon, the wind direction is variable and unstable, and after the transition, the wind direction is stabilized. The winter monsoon affects the East China Coast from the northwest, which transports atmospheric particles from the Northwest Loess Plateau to the East and as far as the North Pacific through westerlies in higher places. Figure 8 shows that, for the Hangzhou and Tiantai stations, the relative contents of $\mathrm{Cu}, \mathrm{Pb}$ and $\mathrm{Zn}$ were clearly different from those in the local soils, indicating an exogenous input of APM during this season when red tides frequently occur in the East China Sea. The summer winds that influenced eastern China mainly were controlled by the East Asian Monsoons, which originated from the areas of high barometric pressure near Australia. The winds cross the equator at $105^{\circ}-125^{\circ} \mathrm{E}$, and turn into the Southwest Airflow above the South China Sea in the Northwest Pacific region. Then, they affect eastern

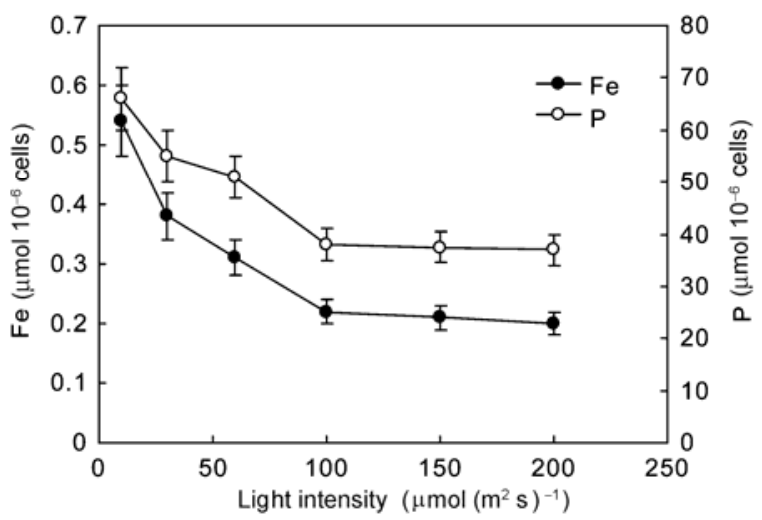

Figure 7 Absorption of $\mathrm{Fe}$ and $\mathrm{P}$ by algal cells under different light intensities.

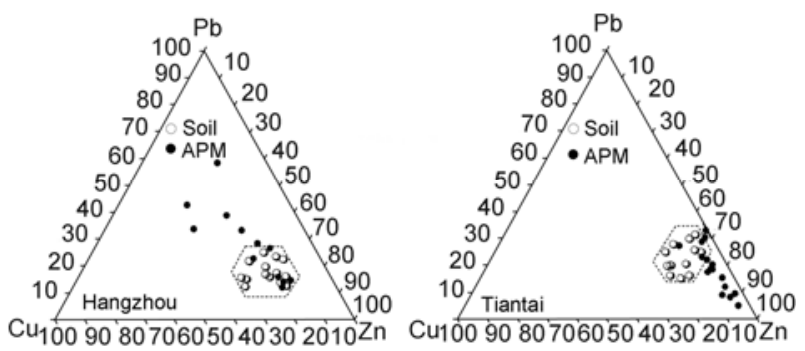

Figure 8 Relative content of $\mathrm{Cu}, \mathrm{Pb}$ and $\mathrm{Zn}$ in $\mathrm{APM}$ and local soil in Hangzhou and Tiantai in May and June.
China and its coast [31]. Air flows brought by the East Asian summer monsoon (also known as East Asian monsoon) from the sea are relatively low with APM. Consequently, the aerosol index (AI) of the atmosphere recorded by the satellite OMI was lower, compared to those in the winter monsoons.

In 2005 and 2006, large-scale red tides in the East China Sea occurred mainly in May and June. This period was considered the winter and summer monsoon conversion period with variable winds. Considering the weather conditions, an average temperature of $20-30^{\circ} \mathrm{C}$ favors algal growth in the East China Sea. In addition, summer monsoons continually bring warm and moist air from the southwest, and winter monsoons transport aerosols from the northwest to the air above the East China Sea. At the same time, aerosols are transferred to the ocean surface with downdrafts, and provide marine organisms with phosphorous and iron nutrients. These favorable hydrodynamic and weather conditions are responsible for the frequent occurrence of red tides. In summary, a potential relationship model between monsoons and red tides in the East China Sea is established (Figure 9). Figure 9 shows that APM is supplied by winter monsoons to the east, and is deposited on the sea by downdrafts. Then, cements between atmospheric particles dissolve into seawater, and provide the limiting iron and phosphorus nutrients needed by phytoplankton. Simultaneously, warm and moist airflow brought by the southwest summer monsoon supplies a favorable hydrodynamic condition for the outbreak of red tides. In addition, downdrafts generate fine weather with sufficient sunlight, which can accelerate the photosynthesis process and increase the bioavailability of nutrients in seawater. This pattern provides suitable meteorological and nutritional conditions for the outbreak of red tides.

Above all, large-scale red tides in the East China Sea

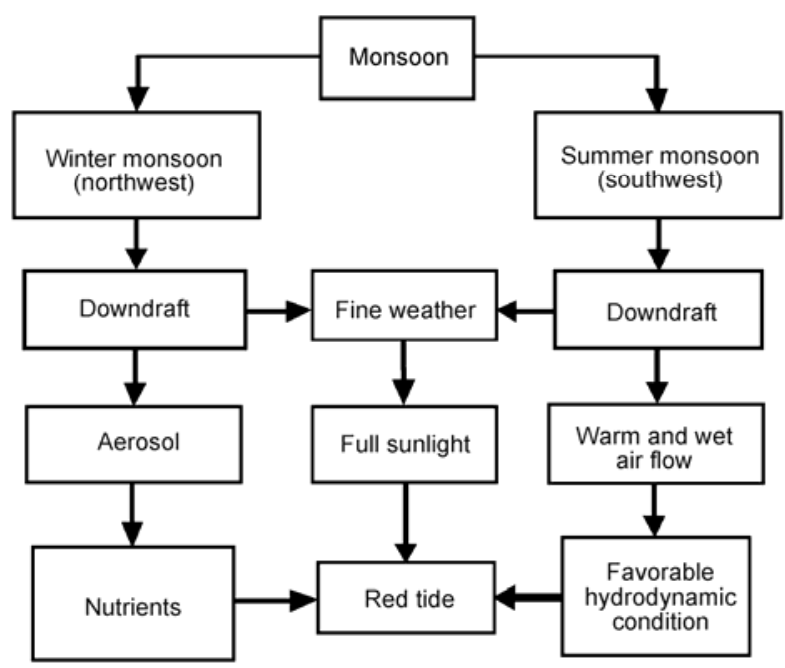

Figure 9 Model for a potential relationship between monsoons and red tides in the East China Sea. 
may be induced by the aerosols transported from the northwest (the direction of the winter monsoon) to the air above the sea and by downdrafts in the same area. With this information, we may forewarn and forecast the occurrence of red tides as part of local weather reports, by monitoring aerosols from the northwest and the vertical airflow characteristics.

\section{Conclusions}

There was a clear correlation between the time of red tide events in the East China Sea and aerosol events above the same area during 2005 and 2006, indicating a relationship in time and space.

During the period of research, every red tide recorded corresponded to downdrafts, showing a causal relationship between aerosols and red tides. Limiting iron and phosphorus nutrients contained in cements of atmospheric particles provided sufficient nutrients for the rapid production of red tide biomass; thus, favoring the outbreak of red tides.

Under low light intensity, algal cells absorbed iron and phosphorus more readily than under high light intensity, suggesting that in clear sunlit conditions the limiting iron and phosphorus nutrients were needed far less for algal growth than in cloudy or rainy weather, which could explain why red tides frequently occurred in fine weather.

The two essential conditions for the outbreak of largescale red tides in the East China Sea are the supply of aerosols from the northwest (the direction of the winter monsoon) to the air above the sea, and the presence of downdrafts in the same area. These downdrafts generate fine weather and transport aerosols to the ocean surface.

This work was supported by the National Natural Science Foundation of China (40572175).

1 Jickells T D, An Z S, Andersen K K, et al. Global iron connections between desert dust, ocean biogeochemistry, and climate. Science, 2005, 308: 67-71

2 Paerl H W. Coastal eutrophication and harmful algal blooms: Importance of atmospheric deposition and groundwater as "new" nitrogen and other nutrient sources. Limnol Oceanogr, 1997, 42: 1154-1165

3 Zou L, Chen H T, Zhang J. Experimental examination of the effects of atmospheric wet deposition on primary production in the Yellow Sea. J Exp Mar Biol Ecol, 2000, 249: 111-121

4 Zhang J, Zou L, Wu Y, et al. Atmospheric wet deposition and changes in phytoplankton biomass in the surface ocean. Geophys Res Lett, 2004, 31, doi:10.1029/2004GL019464

5 Duarte C M, Dachs J, Llabrés M, et al. Aerosol inputs enhance new production in the subtropical northeast Atlantic. J Geophys Res, 2006, 111, doi:10.1029/2005JG000140

6 Baker A R, French M, Linge K L. Trends in aerosol nutrient solubility along a west-east transect of the Saharan dust plume. Geophys
Res Lett, 2006, 33, doi:10.1029/2005GL024764

7 Baker A R, Jickells T D, Witt M, et al. Trends in the solubility of iron, aluminium, manganese and phosphorus in aerosol collected over the Atlantic Ocean. Mar Chem, 2006, 98: 43-58

8 Baker A R, Jickells T D, Biswas K F, et al. Nutrients in atmospheric aerosol particles along the Atlantic Meridional Transect. Deep Sea Res, 2006, 53: 1706-1719

9 Martin J H, Gordon R M. Northeast Pacific iron distributions in relation to phytoplankton productivity. Deep Sea Res, 1988, 35: 177-196

10 Glibert P, Gentien G. Global Ecology and Oceanography of Harmful Algal Blooms, Science Plan. Baltimore and Paris: SCOR and IOC, 2001.86

$11 \mathrm{Su}$ J L. Harmful algae bloom and its research in China (in Chinese). Bull Chin Acad Sci, 2001, 5: 339-342

12 Hua Z A. Red Tide Disaster (in Chinese). Beijing: China Ocean Press, 1994. 31-42

13 Tian R X. Relationship between East Asian summer monsoon and the harmful algal bloom over East China Sea (in Chinese). J Zhejiang Univ, 2005, 32: 355-360

14 Zhang J H, Xia X, Liu X Q, et al. Progress and prospect on red tide research (in Chinese). Environ Monit Chin, 2002, 18: 20-26

15 Weng H X, Sun X W, Chen J F, et al. Limit and synergetic effects of iron and phosphorus on proliferation of Prorocentrum micans Ehrenberg and Cryptomonas (in Chinese). Prog Nat Sci Chin, 2006, 16: 705-711

16 Abram N J, Gagan M K, McCulloch M T, et al. Coral reef death during the 1997 Indian Ocean Dipole linked to Indonesian wildfires. Science, 2003, 301: 952-955

17 Walsh J J, Steidinger K A. Saharan dust and Florida red tides: The Cyanophyte connection. J Geophy Res, 2001, 106: 11597-11612

18 Fernández A J, Temero M, Barragán F J, et al. An approach to characterization of sources of urban airborne particles through heavy metal speciation. Chemosphere, 2000 2: 123-136

19 National Climate Centre of China. East Asian Monsoon Monitoring Bull (in Chinese), 2008, 6: 1-5

20 National Climate Centre of China. East Asian Monsoon Monitoring Bull (in Chinese), 2008, 8: 1-5

21 Boyd P W, Watson A J, Law C S, et al. A mesoscale phytoplankton bloom in the polar Southern Ocean stimulated by iron fertilization. Nature, 2000, 407: 695-701

22 Dalton R. Squaring up over ancient life. Nature, 2002, 417: 782-784

23 Cao Y, Li D J, Zhang J. Progress in the research of iron limitation to marine phytoplankton (in Chinese). Mar Sci Bull, 2002, 21: 83-90

24 Eyre B D, McKee L J. Carbon, nitrogen, and phosphorus budgets for a shallow subtropical coastal embayment (Moreton May, Australia). Limnol Oceanogr, 2002, 47: 1043-1055

25 Qi Y Z. Red Tides in Coastal China Sea (in Chinese). Beijing: Science Press, 2003. 62-87

26 McElory M B. Marine biological controls on atmospheric $\mathrm{CO}_{2}$ and climate. Nature, 1983, 302: 328-329

27 Huo W Y, Yu Z M, Zou J Z, et al. Outbreak of Skeletonema Costatum red tide and its relations to environmental factors in Jiaozhou Bay (in Chinese). Oceanol Limnol Sin, 2001, 32: 311-318

28 Hong J C, Huang X Q, Jiang X S. Analysis of the dominant factor during the outbreak of Skeletonema Costatum red tide (in Chinese). Acta Oceanol Sin, 1993, 15: 135-141

29 Huang R H. Introduction to Atmospheric Sciences (in Chinese). Beijing: China Meteorological Press, 2005. 98-136

30 Weng H X, Sun X W, Qing Y C, et al. Effect of irradiance on Fe and P uptake by Cryptomonas (in Chinese). Geochimica, 2007, 36: 383390

31 Wu R S. Principal in Modern Synoptic Meteorology (in Chinese). Beijing: Higher Education Press, 1991. 209-237

Open Access This article is distributed under the terms of the Creative Commons Attribution License which permits any use, distribution, and reproduction in any medium, provided the original author(s) and source are credited. 